\title{
Carcass Yield and Composition of Supplementing Hararghe Highland Sheep with Ficus sur (cv. Forssk.) Fruits to a Basal Diet of Natural Pasture Hay
}

\author{
Diriba Diba $^{1^{*}}$, Yoseph Mekasha ${ }^{2,3}$, Mengistu Urge ${ }^{3}$, and Adugna Tolera ${ }^{4}$ \\ ${ }^{1}$ Department of Animal Sciences, College of Agriculture and Natural Resources, Wollega University, \\ P.O. Box: 395, Nekemte, Ethiopia \\ ${ }^{2}$ International Livestock Research Institute, P.O. Box: 5689, Addis Ababa, Ethiopia \\ ${ }^{3}$ School of Animal and Range Sciences, Haramaya University, P.O. Box: 138, Dire Dawa, Ethiopia \\ ${ }^{4}$ School of Animal and Range Sciences, College of Agriculture, Hawassa University, P.O. Box: 05, \\ Hawassa, Ethiopia
}

\begin{abstract}
The experiment was conducted to evaluate the supplementary value of dried and ground Ficus sur fruits (FSF) mixed at different proportions with oats grain (OG) on carcass yield, carcass composition, and $\mathrm{pH}$ concentration. Thirty Hararghe highland lambs with initial live weights of $14.32 \pm 0.25 \mathrm{~kg}$ (mean $\pm S E M)$ were used for the experiment. The experimental sheep were grouped into 5 based on their initial body weight. Thus, the experiment was laid out in a randomized complete block design (RCBD) consisting of 5 treatments and 6 replications. The treatments were: ad libitum natural pasture hay (control); 100\%FSF:0\%OG [100FSF]; 67\%FSF:33\%OG [67FSF]; 33\%FSF:67\%OG [33FSF]; 0\%FSF:100\%OG [OFSF], which were randomly assigned to the sheep in each block. Noug seed (Gizotia abysinica) cake (NSC) was supplemented at isonitrogenous levels to all treatments and control diets. No significant $(P>0.05)$ effect of the dietary treatments was observed on carcass parameters and most of the edible and non-edible offal components. The carcass of lambs fed 100FSF diet consist the highest $(P<0.001)$ moisture and crude protein $(C P)$, but the least ether extract (EE) as compared to those consumed OFSF diet. The pH of the carcass consistently declined from the initial measure taken at 45 minutes post-evisceration to measurement taken at 24 hours. Carcass of lamb fed treatment diets 67FSF and 100FSF have better maintained $\mathrm{pH}$ value within the desirable range. Hence, it can be concluded that feeding FSF to Hararghe highland sheep as a supplement to natural pasture hay based diet with sufficient protein supplement improved carcass yield and $\mathrm{pH}$ as compared to oat grains.
\end{abstract}

Copyright@2015 STAR Journal, Wollega University. All Rights Reserved.
Article Information

Article History:

Received : 27-09-2015

Revised : 14-12-2015

Accepted : 26-12-2015

\begin{tabular}{l}
\hline Keywords: \\
Carcass \\
Feed resources \\
Ficus sur fruits \\
Sheep \\
\hline *Corresponding Author: \\
Diriba Diba \\
E-mail: \\
diriba.diba@yahoo.com \\
dnazerawi2010@gmail.com \\
\hline
\end{tabular}

\section{INTRODUCTION}

Livestock sector is the backbone of agriculture in Ethiopia whereby most domestic animals serve as sources of food, income, and supporting crop productions in different ways. Among livestock resources, sheep is the second populous to cattle with an estimate number of about 26 million (IGAD, 2009). Sheep production is widely practiced in Ethiopia due to many important attributes such as quantitatively low feed requirement and low initial cost of production (Adane, 2008); ease of handling; docile temperament; fast return; adaptation to diverse climates and production systems as compared to large ruminants (Khan et al., 2003). Among many other products of sheep, mutton is the main product utilized by all Ethiopian communities (Addass et al., 2010), with no discrimination by all religious groups, age, and gender. However, despite the potential, meat production from sheep in the country remained low.
Among the major constraints that limit sheep production, in general, feed shortage is on the top of the list of factors (Adane and Girma, 2008). According to Alemu (2008), about two-third of livestock production in Ethiopia is affected by nutrition. Research reports (Adugna, 2007; Yoseph et al., 2002) have shown that natural pasture and crop residues are the major sources of animal feeds in Ethiopia. However, these feed resources are poor in energy and crude protein contents and their quantity is not sufficient to support livestock, particularly during the dry season where there is critical feed shortage. Supply of conventional supplements such as agro-industrial by-products is limited and its price remains escalating, which hinders its use as supplement by smallholder farmers. Although grains such as oats grains can be used as energy supplement, it becomes staple diet for human being in most part of the country and not economical to use as animal feed. It is, therefore, 
Diriba Diba et al.,

imperative to search for alternative non-conventional feeds.

Ficus sur fruits (FSF) is naturally available feed resource in many parts of the tropics. It contains high amount of soluble carbon and could be used as energy supplement to poor quality natural feeds such as natural pasture and crop residues. Ficus sur is widely distributed in most part of Ethiopia and are freely accessed by smallholder farmers. In the country, FSF has been used locally as feed for centuries by different classes of livestock. During the dry season, the fruits are ripen and fall on the ground and are easily accessed and consumed by animals. Thus, it serves as an important supplement to animal grazing on poor pasture and crop aftermath. Moreover, Ficus sur trees serve as natural shade and resting area to livestock, which can be considered as an important role of the tree since the high environmental temperature is one of the stressors to the extensive system of animal production, particularly under the scenario of the current global temperature rise.

Despite its importance, the effect of this fruit on product yield and quality of replacing the fruit with other energy supplement has not been studied. Therefore, this study was aimed at evaluating the effects of feeding FSF on carcass yield, composition and $\mathrm{pH}$ concentration of Hararghe highland sheep as compared to feeding oats grain.

\section{MATERIALS AND METHODS}

\section{Study Site}

The study was conducted at Haramaya University sheep farm, located at $9^{\circ} 26^{\prime} \mathrm{N}$ latitude and $42^{\circ} 3^{\prime} \mathrm{E}$ longitude in eastern Ethiopia. The altitude of the area is about 1980 meters above sea level and the mean annual rainfall is about $910 \mathrm{~mm}$ with a range of $560-1260 \mathrm{~mm}$.
Sci. Technol. Arts Res. J., Oct-Dec 2015, 4(4): 09-17

The mean maximum and minimum temperatures are 23.4 and $8.25{ }^{\circ} \mathrm{C}$, respectively (summary report from Haramaya University Meteorological Station, 2012).

\section{Animals and Management}

A total of 30 yearling intact male Hararghe highland sheep with similar body condition were purchased from Kulubi open market. The animals were transported to Haramaya University and quarantined for 3-weeks during which they were sprayed with accaricides against external parasites; treated with ivermectin injection against internal parasites and Penistrep against Pneumonia disease. During this period, animals were fed with natural pasture hay with noug seed cake supplement. At the end of the quarantine period, healthy animals with uniform condition were selected for the study and provided with ear-tag. The animals were randomly assigned to individual pens furnished with feeder and waterer in the experiment house.

\section{Treatments and Experimental Design}

The different dietary treatments used in the experiments are natural pasture hay offered ad libitum (control); natural pasture hay ad libitum and supplemented with either of the four diets, namely $100 \%$ Ficus sur fruits (FSF) and $0 \%$ oat grain(OG) [100FSF], $67 \% \mathrm{FSF}$ and $33 \% \mathrm{OG}$ [67FSF]; $33 \% \mathrm{FSF}$ and $67 \% \mathrm{OG}$ [33FSF]; or $0 \%$ FSF and $100 \%$ OG [OFSF]. Noug seed cake (NSC) was included in the diet across all the treatments to meet the protein requirement for maintenance at isonitrogenous level. The experiment was laid out in a randomized complete block design (RCBD) with five treatments. The animals were grouped into six blocks based on their initial body weight and dietary treatments were randomly distributed to the animals within each block.

Table 1: Treatments and chemical composition of feed stuff on DM basis

\begin{tabular}{lccccc}
\hline \multirow{1}{*}{ Ingredients (g) } & \multicolumn{5}{c}{ Treatments } \\
\cline { 2 - 6 } & Control & 100FSF & 67FSF & 33FSF & 0FSF \\
\hline Ficus sur fruits & 0 & 300 & 201 & 99 & 0 \\
Oats grain & 0 & 0 & 99 & 201 & 300 \\
Noug seed cake & 225 & 210 & 190 & 170 & 150 \\
\hline Chemical composition (\%) & & & & & \\
Dry matter & 91.8 & 91.4 & 91.4 & 91.4 & 91.4 \\
Ash & 9.3 & 8.1 & 7.3 & 6.9 & 5.6 \\
Crude protein & 15.4 & 15.4 & 15.4 & 15.4 & 15.4 \\
Neutral detergent fiber & 58.3 & 33.7 & 35.2 & 36.8 & 38.6 \\
Acid detergent fiber & 41.1 & 22.6 & 23.1 & 23.7 & 24.3 \\
Hemicelluloses & 17.1 & 11.1 & 12.0 & 13.1 & 14.3 \\
Cellulose & 33.6 & 17.2 & 17.7 & 18.3 & 18.8 \\
Acid detergent lignin & 7.6 & 5.4 & 5.4 & 5.5 & 5.5 \\
ME calculated (MJ/kg DM) & 8.6 & 10.4 & 10.2 & 9.9 & 9.6 \\
\hline
\end{tabular}

$\mathrm{FSF}=$ Ficus sur fruits; $\mathrm{ME}=$ metabolizable energy; $\mathrm{DM}=$ dry matter ${ }^{*}$ Natural pasture hay was offered ad libitum whereas noug seed cake was given to make the diets of all animals isonitrogenous; $100 \mathrm{FSF}=100 \% \mathrm{FSF}$ with $0 \%$ oats grain; $67 \mathrm{FSF}=67 \% \mathrm{FSF}$ with $33 \%$ oats grain;

$33 \mathrm{FSF}=33 \% \mathrm{FSF}$ with $67 \%$ oats grain; $\mathrm{OFSF}=0 \% \mathrm{FSF}$ with $100 \%$ oats grain

\section{Experimental Feeds and Feeding Management}

Naturally ripen and dry FSF were collected from fig trees in Horro district, western Ethiopia, packed in clean sacks and taken to Haramaya University sheep farm. The fruits were further sun dried to ensure grinding of the feed in conventional flour mill. The OG was purchased from Sheno town of North Shoa zone of Oromia National
Regional State, ground in similar mill and taken to sheep farm where FSF were stored. The two feeds were used as energy supplement and mixed at different proportions as shown in Table 1.

During the study, sheep were allowed to adapt with the treatment diets for two weeks. After completion of 
Diriba Diba et al.,

adaptation period, they were offered measured quantity of the diets. Clean tap water was provided in a bucket and changed whenever contaminated with feces or feed material. The basal diet (natural pasture hay) and concentrate supplement were offered in a separate feeding material. The amount of feeds offered and refused was measured and recorded every day. The basal diet offer was adjusted at interval of 3 days for ad libitum intake at $20 \%$ refusal. The live weight change of the animals was recorded every fortnight. The experiment lasted for 90 days.

\section{Chemical Analysis of the Experimental Diets}

The chemical analysis of the basal diet and the concentrates were performed at Haramaya University Animal Nutrition laboratory. During the feeding periods, feed samples were taken each day and bulked in a separate bag. At the end of the feeding trial, the feed in the bag was thoroughly mixed and ample sample was processed for chemical analysis in the laboratory.

The samples were partially dried in a forced draft oven at $65^{\circ} \mathrm{C}$ to constant weight. The dried samples were ground to pass a $1 \mathrm{~mm}$ sieve size Wiley mill and collected into a labeled crucible and placed in desiccators to equilibrate with air at room temperature. The samples were then put in air tight plastic bag and kept in the laboratory until required for further analysis. The chemical analysis for each sample was run in duplicate. When the difference between the duplicates exceeds $5 \%$, the analysis was repeated. The dry matter (DM) and ash contents of the feed samples were determined following the procedure of AOAC (1995). The NDF, ADF, and ADL were determined based on the method described by Van soest and Robertson (1985). Hemicelluloses and cellulose were calculated as NDF-ADF and ADF-(ADL+ADF ash), respectively. The $M E(M J / k g)$ of the diets was estimated according to the procedure described by Moran (2005). The nitrogen $(\mathrm{N})$ content of the samples was determined by the micro-Kjeldahl method and $\mathrm{CP}$ was calculated as $\mathrm{N}$ $\times 6.25$

\section{Carcass Measurements and Chemical Analysis}

At the end of the feeding trial, all sheep were fasted overnight, weighed, and slaughtered. On slaughtering, the animals were killed by cutting their jugular vein and carotid artery with knife. Their blood was taken in separate container and weighed. During slaughtering process, data were carefully recorded and the carcass was dismembered into its component parts namely, loin, forelegs, hind legs, brisket, rib with muscle, neck, and tail fat. The non-carcass components were also partitioned into edible viscera, which include blood, empty gut, heart, heart fat, liver with gall bladder, kidney, kidney fat, tail, omental and intestinal fat, and tongue and non-edible viscera, which is represented by gut content, penis with fat, spleen, testicles, lungs, trachea, esophagus, head without tongue, limbs, and skin. The edible and non-edible components of the viscera were identified according to meat eating habit in the country. Digital balance was used for weighing carcass and organs.

The empty body weight (EBW) was calculated as the difference between slaughter weight (SW) and gut content, skin and limbs. Dressing percentage was calculated as the percentage of HCW from SW. The ribeye area (REA), both the right and left halves, were cut between the $12^{\text {th }}$ and $13^{\text {th }}$ ribs perpendicular to the
Sci. Technol. Arts Res. J., Oct-Dec 2015, 4(4): 09-17

backbone to measure the cross sectional area of the ribeye muscle. The rib-eye muscle area was traced on transparency paper and the area was drawn using permanent ink marker. Then this transparent paper was traced on graph paper and the area was measured by calculating the area of the squares on the graph paper and multiplying by the number of the squares in the area. The average of the left and the right longisimus dorsi muscle cross-sectional area was recorded for each animal.

The DM and ash contents of the carcass samples were determined following AOAC (1995). The moisture content was determined by weight difference before and after drying the carcass sample at $100^{\circ} \mathrm{C}$ to constant weight. The proximate composition of the sample for ether extract (EE) and crude fiber (CF) were determined according to AACC (2000). The $\mathrm{N}$ content was determined by the micro-Kjeldahl method and crude protein $(\mathrm{CP})$ was calculated as $\mathrm{N}^{*} 6.25$.

\section{Carcass pH Measurement}

The longisimus dorsi muscle $(10 \mathrm{~g})$ was taken as duplicate sample, and cut into small pieces finely and uniformly. The samples were filled into a clean beaker of $100 \mathrm{ml}$ volume to a depth of $4 \mathrm{~cm}$. About $10 \mathrm{ml}$ of distilled water was added to each sample and homogenized for one minute and left to rest until the equipment was adjusted to working temperature. The electrode of Demetra model PM 53D portable $\mathrm{pH}$ meter was vertically submerged into the solution to a depth of $2 \mathrm{~cm}$ avoiding contact of the probe with fat and connective tissues and hold for 30 seconds until the reading became stable. The electrode was cleaned with distilled water between sample measurements. The $\mathrm{pH}$ reading for all samples was taken at $45 \mathrm{~min}$ and $6,12,18$, and 24 hours following evisceration of the carcass.

\section{Statistical Analysis}

Data on carcass yield and compositions were analyzed using the General Linear Model of the statistical analysis system (SAS) (2008) procedure. Treatment means were compared using Tukey honestly significant difference test. The data and graphics on $\mathrm{pH}$ concentration of the longissimus dorsi muscle were summarized, described and plotted using excels spreadsheet. The model for the analysis of carcass yield and composition was:

$$
Y i j k=\mu+T i+\beta j+\varepsilon i j k
$$

where, $\mu=$ overall mean of the population; $\mathrm{i}=\mathrm{i}^{\text {th }}$ treatment; $\beta j=j^{\text {th }}$ block and $\varepsilon i j k=$ random error

\section{RESULTS}

\section{Nutrient Composition of Major Experimental Diets}

As depicted in Table 1, DM and CP contents of the experimental diets are similar. The ash content was higher in the control diet and consistently decreased with decreasing level of FSF in the diet. The NDF, ADF, cellulose, hemicelluloses and lignin contents were higher in the control than in the supplemented diets and these were in opposite trend of the ash levels in the diet. On the other hand, the ME content was lower in the control than in the supplemented diets and increased with increasing level of FSF in the diet. 
Diriba Diba et alo,

\section{Carcass Yield and Primal Cuts}

The effect of supplementing Hararghe highland sheep with dried and ground FSF is presented in Table 2. Although there was numerical difference between the control and treatment diets (100FSF, 67FSF, 33FSF, and OFSF), the analysis of variance did not show significant difference $(P>0.05)$ for all carcass parameters studied.
Sci. Technol. Arts Res. J., Oct-Dec 2015, 4(4): 09-17

Animals consumed the control diet had numerically lower slaughter measures and carcass cuts than the average of the other treatments. Among the treatment diets, 100FSF resulted in relatively higher magnitude of slaughter and hot carcass weight, and dressing percentage compared to other treatment diet.

Table 2: Carcass yield and primal cuts of Hararghe highland lambs fed a basal diet of natural pasture hay supplemented with different proportions of FSF and oats grain

\begin{tabular}{|c|c|c|c|c|c|c|c|}
\hline \multirow[t]{2}{*}{ Carcass measurements } & \multicolumn{4}{|c|}{ Treatments } & & \multirow[t]{2}{*}{ SEM } & \multirow[t]{2}{*}{ SL } \\
\hline & control & 100FSF & 67FSF & 33FSF & OFSF & & \\
\hline \multicolumn{8}{|l|}{ Slaughter characteristics } \\
\hline Slaughter weight $(\mathrm{kg})$ & 16.1 & 18.3 & 18.4 & 17.4 & 16.9 & 0.98 & ns \\
\hline Empty body weight $(\mathrm{kg})$ & 11.4 & 13.8 & 13.7 & 13.2 & 12.2 & 0.91 & ns \\
\hline Hot carcass weight $(\mathrm{kg})$ & 6.08 & 8.0 & 7.72 & 7.26 & 6.83 & 0.61 & ns \\
\hline Dressing percentage (\%) & 37.7 & 43.1 & 41.8 & 41.7 & 40.1 & 1.65 & ns \\
\hline Rib-eye-area $\left(\mathrm{cm}^{2}\right)$ & 6.48 & 6.67 & 6.87 & 6.10 & 6.29 & 0.42 & ns \\
\hline \multicolumn{8}{|l|}{ Carcass cuts $(\mathbf{k g})$ : } \\
\hline Loin $(\mathrm{kg})$ & 1.28 & 1.40 & 1.47 & 1.31 & 1.27 & 0.13 & ns \\
\hline Forelegs (kg) & 1.16 & 1.45 & 1.47 & 1.31 & 1.41 & 0.09 & ns \\
\hline Hind legs (kg) & 1.58 & 1.89 & 1.84 & 1.69 & 1.71 & 0.14 & ns \\
\hline Brisket $(\mathrm{kg})$ & 0.52 & 0.72 & 0.62 & 0.64 & 0.59 & 0.06 & ns \\
\hline Rib-with-muscle (kg) & 1.00 & 1.18 & 1.05 & 1.09 & 0.89 & 0.11 & ns \\
\hline Neck (kg) & 0.58 & 0.75 & 0.68 & 0.61 & 0.62 & 0.05 & ns \\
\hline Tail fat $(\mathrm{kg})$ & 0.38 & 0.72 & 0.70 & 0.62 & 0.65 & 0.09 & ns \\
\hline
\end{tabular}

\section{Non-carcass Components}

\section{Edible Non-carcass Components}

Consistent with carcass parameters, there was no difference $(P>0.05)$ in most edible non-carcass components among the dietary treatments compared (Table 3). However, liver with gall bladder, kidney, reticulo-rumen, and omentum and mesenteric fats showed significant difference $(P<0.05)$ among the treatments and the control diets. The relative weight of liver with gall bladder and reticulo-rumen were significantly $(P<0.05)$ higher in OFSF compared to animals consumed the control whereas, the weight of the kidney and omentum and mesenteric fat were highest for 67FSF.

Table 3: Non-carcass edible component of Hararghe highland lambs fed a basal diet of natural pasture hay supplemented with different proportions of FSF and oats grain

\begin{tabular}{lllllllc}
\hline \multicolumn{1}{c}{ Edible offal } & \multicolumn{9}{c}{ Treatments } & & \\
\cline { 2 - 6 } \multicolumn{1}{c}{ components (kg) } & control & 100FSF & 67FSF & 33FSF & 0FSF & SEM & SL \\
\hline Blood & 0.54 & 0.58 & 0.58 & 0.56 & 0.54 & 0.04 & $\mathrm{Ns}$ \\
Empty gut & 0.937 & 1.01 & 1.11 & 1.02 & 1.11 & 0.07 & $\mathrm{Ns}$ \\
Heart & 0.06 & 0.08 & 0.07 & 0.07 & 0.07 & 0.03 & $\mathrm{Ns}$ \\
Heart fat & 0.13 & 0.03 & 0.03 & 0.12 & 0.26 & 0.05 & $\mathrm{Ns}$ \\
Liver with gall balder & $0.18^{\mathrm{b}}$ & $0.19^{\mathrm{ab}}$ & $0.23^{\mathrm{ab}}$ & $0.24^{\mathrm{ab}}$ & $0.25^{\mathrm{a}}$ & 0.02 & $*$ \\
Kidney & $0.04^{\mathrm{b}}$ & $0.05^{\mathrm{ab}}$ & $0.06^{\mathrm{a}}$ & $0.05^{\mathrm{ab}}$ & $0.05^{\mathrm{ab}}$ & 0.01 & $*$ \\
Kidney fat & 0.04 & 0.04 & 0.04 & 0.05 & 0.03 & 0.01 & $\mathrm{Ns}$ \\
Reticulo-rumen & $0.36^{\mathrm{b}}$ & $0.41^{\mathrm{ab}}$ & $0.44^{\mathrm{ab}}$ & $0.43^{\mathrm{ab}}$ & $0.48^{\mathrm{a}}$ & 0.02 & $*$ \\
Omentum and mesen. fat & $0.04^{\mathrm{b}}$ & $0.06^{\mathrm{ab}}$ & $0.13^{\mathrm{a}}$ & $0.07^{\mathrm{ab}}$ & $0.07^{\mathrm{ab}}$ & 0.02 & $*$ \\
Omaso-abomasum & 0.13 & 0.13 & 0.16 & 0.14 & 0.14 & 0.01 & $\mathrm{Ns}$ \\
Tongue & 0.05 & 0.06 & 0.06 & 0.06 & 0.07 & 0.01 & $\mathrm{Ns}$ \\
Small Intestine & 0.28 & 0.30 & 0.31 & 0.33 & 0.36 & 0.02 & $\mathrm{Ns}$ \\
Large-Intestine & 0.16 & 0.17 & 0.19 & 0.18 & 0.19 & 0.02 & $\mathrm{Ns}$ \\
TEOC & 2.93 & 3.16 & 3.47 & 3.22 & 3.37 & 0.16 & $\mathrm{Ns}$ \\
\hline
\end{tabular}

${ }^{\mathrm{ab}}$ Means with different superscript letter in the same row differ; FSF=Ficussur fruits; $100 \mathrm{FSF}=100 \% \mathrm{FSF}$ and $0 \% \mathrm{MG}$; $67 \mathrm{FSF}=67 \% \mathrm{FSF}$ and $33 \% \mathrm{MG} ; 33 \mathrm{FSF}=33 \% \mathrm{FSF}$ and $67 \% \mathrm{MG} ; 0 \mathrm{FSF}=0 \% \mathrm{FSF}$ and $100 \% \mathrm{MG}$; control diet=natural pasture hay; $\mathrm{SEM}=$ Standard error of the mean; ns= non-significant; SL=significance level; $100 \mathrm{FSF}=100 \% \mathrm{FSF}$ with $0 \%$ oats grain; $67 \mathrm{FSF}=67 \% \mathrm{FSF}$ with $33 \%$ oats grain; $33 \mathrm{FSF}=33 \% \mathrm{FSF}$ with $67 \%$ oats grain; $\mathrm{FSSF}=0 \% \mathrm{FSF}$ with $100 \%$ oats grain 
Diriba Diba et alo,

\section{Non-edible Non-Carcass Components}

The treatment diets did not affect $(P>0.05)$ the nonedible non-carcass components, except penis with fat and
Sci. Technol. Arts Res. J., Oct-Dec 2015, 4(4): 09-17

esophagus, which showed difference among treatments, but with no consistent trend (Table 4).

Table 4: Non-edible non-carcass component of Hararghe highland lambs fed a basal diet of natural pasture hay supplemented with different proportion of FSF and oats grain

\begin{tabular}{|c|c|c|c|c|c|c|c|}
\hline \multirow{2}{*}{$\begin{array}{l}\text { Non-edible offal } \\
\text { components }(\mathrm{kg})\end{array}$} & \multicolumn{4}{|c|}{ Treatments } & \multirow[b]{2}{*}{ OFSF } & \multirow[b]{2}{*}{ SEM } & \multirow[b]{2}{*}{ SL } \\
\hline & control & 100FSF & 67FSF & 33FSF & & & \\
\hline Head without tongue & 1.13 & 1.17 & 1.22 & 1.29 & 1.28 & 0.05 & Ns \\
\hline Limbs & 0.36 & 0.41 & 0.44 & 0.42 & 0.45 & 0.02 & $\mathrm{Ns}$ \\
\hline Skin & 1.75 & 1.99 & 2.46 & 2.25 & 2.32 & 0.24 & $\mathrm{Ns}$ \\
\hline Gut content & 4.67 & 4.25 & 4.70 & 4.58 & 4.74 & 0.39 & Ns \\
\hline Penis with fat & $0.06^{\mathrm{b}}$ & $0.08^{\mathrm{ab}}$ & $1.08^{\mathrm{ab}}$ & $1.10^{a}$ & $0.08^{\mathrm{ab}}$ & 0.01 & * \\
\hline Spleen & 0.05 & 0.03 & 0.03 & 0.03 & 0.03 & 0.01 & Ns \\
\hline Testicles & 0.15 & 0.19 & 0.20 & 0.23 & 0.20 & 0.02 & Ns \\
\hline Lungs & 0.14 & 0.19 & 0.19 & 0.17 & 0.21 & 0.01 & Ns \\
\hline Trachea & 0.07 & 0.07 & 0.06 & 0.05 & 0.08 & 0.01 & Ns \\
\hline Esophagus & $0.02^{\mathrm{b}}$ & $0.03^{\mathrm{ab}}$ & $0.03^{a}$ & $0.03^{\mathrm{a}}$ & $0.04^{a}$ & 0.01 & *** \\
\hline TNEOC & 8.42 & 8.40 & 9.43 & 9.16 & 9.43 & 0.66 & Ns \\
\hline
\end{tabular}

\section{Carcass Composition}

Animals fed with sole FSF (100FSF) had the highest carcass DM and CP followed by 67FSF, except for ether extract (Table 5). Animals fed with 33FSF and OFSF had similar carcass DM and CP, which is significantly higher $(P<0.05)$ compared to the control. The DM composition of the carcass tended to consistently increase with increasing levels of FSF in the diets.

Table 5: Chemical composition of carcass of Hararghe highland sheep fed a basal diet of grass pasture hay supplemented with different proportions of FSF and oats grain

\begin{tabular}{|c|c|c|c|c|c|c|c|}
\hline \multirow[b]{2}{*}{ Composition (\% DM) } & \multicolumn{5}{|c|}{ Dietary treatments } & \multirow[b]{2}{*}{ SEM } & \multirow[b]{2}{*}{ SL } \\
\hline & control & 100FSF & 67FSF & 33FSF & OFSF & & \\
\hline Moisture & $69.8^{\mathrm{C}}$ & $72.7^{\mathrm{a}}$ & $71.3^{\mathrm{D}}$ & $70.1^{\mathrm{C}}$ & $69.4^{\mathrm{C}}$ & 0.21 & $* * *$ \\
\hline Dry matter & $30.6^{a}$ & $27.3^{\mathrm{c}}$ & $28.7^{\mathrm{b}}$ & $29.9^{a}$ & $30.6^{a}$ & 0.20 & *** \\
\hline Total ash & 2.07 & 2.03 & 2.37 & 2.27 & 1.93 & 0.26 & ns \\
\hline Ether Extract & $4.87^{\mathrm{b}}$ & $5.31^{\mathrm{b}}$ & $6.27^{a}$ & $6.57^{\mathrm{a}}$ & $6.77^{\mathrm{a}}$ & 0.15 & *** \\
\hline Crude Protein & $19.4^{c}$ & $21.5^{\mathrm{a}}$ & $21.2^{\mathrm{a}}$ & $20.4^{\mathrm{b}}$ & $20.1^{\mathrm{b}}$ & 0.09 & *** \\
\hline
\end{tabular}

\section{Carcass pH}

Table 6 indicates the effect of dietary treatments on $\mathrm{pH}$ values of sheep carcass at different hours. The overall

mean carcass $\mathrm{pH}$ was significantly different $(\mathrm{P}<0.0001)$ among the treatments.

Table 6: Effect of dietary treatments on $\mathrm{pH}$ values of sheep Carcass at different post-evisceration hours

\begin{tabular}{|c|c|c|c|c|c|c|c|}
\hline \multirow[t]{2}{*}{ pH after* } & \multicolumn{5}{|c|}{ Dietary treatments } & \multirow[t]{2}{*}{ SEM } & \multirow[t]{2}{*}{ SL } \\
\hline & Control & 100FSF & 67FSF & 33FSF & OFSF & & \\
\hline O hours & $7.8^{\mathrm{a}}$ & $6.9^{\mathrm{d}}$ & $7.2^{\mathrm{C}}$ & $7.3^{\mathrm{DC}}$ & $7.4^{\mathrm{D}}$ & 0.036 & $* * *$ \\
\hline 6 hours & $7.0^{\mathrm{a}}$ & $6.3^{\mathrm{d}}$ & $6.6^{\mathrm{c}}$ & $6.7^{\mathrm{bc}}$ & $6.8^{\mathrm{b}}$ & 0.035 & *** \\
\hline 12 hours & $6.6^{a}$ & $5.9^{d}$ & $6.2^{c}$ & $6.3^{\mathrm{bc}}$ & $6.4^{\mathrm{b}}$ & 0.036 & $* * *$ \\
\hline 18 hours & $6.2^{\mathrm{a}}$ & $5.6^{\mathrm{d}}$ & $5.9^{c}$ & $6.0^{\mathrm{bc}}$ & $6.1^{\mathrm{b}}$ & 0.035 & $* * *$ \\
\hline 24 hours & $6.0^{\mathrm{a}}$ & $5.3^{\mathrm{d}}$ & $5.7^{\mathrm{C}}$ & $5.8^{\mathrm{bc}}$ & $5.9^{\mathrm{b}}$ & 0.036 & $* * *$ \\
\hline
\end{tabular}

${ }^{\text {abc }}$ Means with different superscript letter in the same row differ; *0 hour= 45 min post-evisceration; FSF $=$ Ficus sur fruits; $100 \mathrm{FSF}=100 \% \mathrm{FSF}$ and $0 \% \mathrm{MG} ; 67 \mathrm{FSF}=67 \% \mathrm{FSF}$ and $33 \% \mathrm{MG}$ $33 \mathrm{FSF}=33 \% \mathrm{FSF}$ and $67 \% \mathrm{MG} ; \mathrm{OFSF}=0 \% \mathrm{FSF}$ and $100 \% \mathrm{MG}$; control diet=natural pasture hay; SEM=Standard error of the mean; ns= non-significant; SL=significance level.

The $\mathrm{pH}$ consistently decreased with increase in time after evisceration irrespective of the difference among the treatments (Figure 2). However, carcass pH was slightly lower for lambs supplemented with different proportions of
FSF compared to the control. Among dietary treatments, animals in 100FSF maintained the lowest carcass $\mathrm{pH}$ throughout the measurement time followed by 67FSF. 


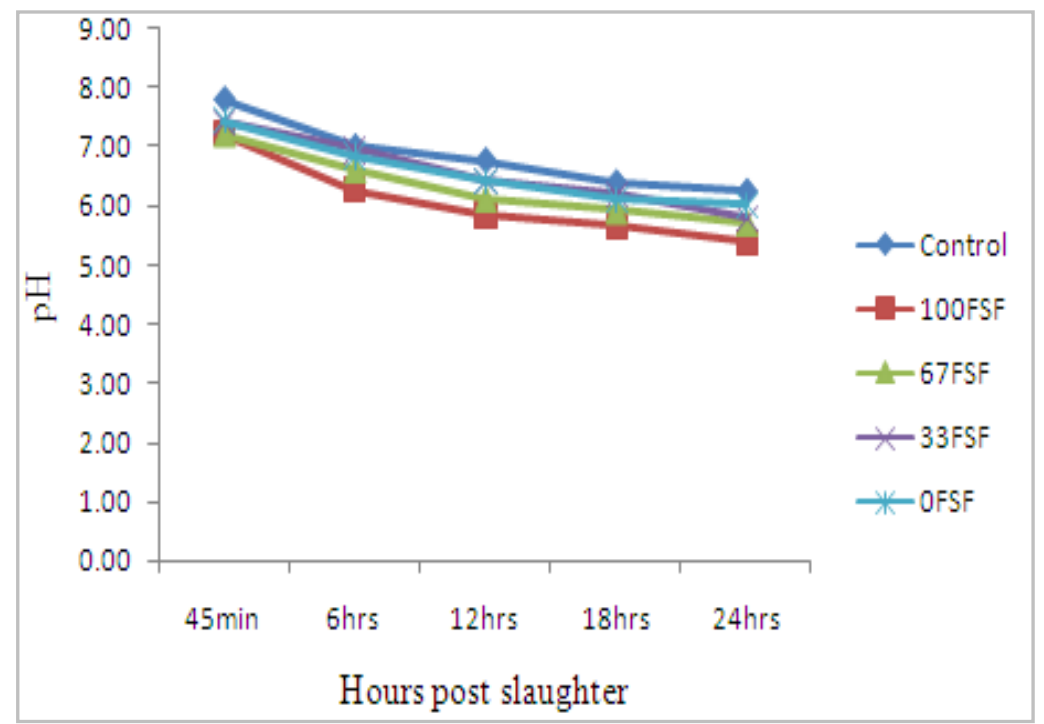

Figure 1: $\mathrm{pH}$ concentration of carcass of lambs fed with different proportion of Ficus sur fruits and oats grain across post-evisceration time

\section{DISCUSSION}

\section{Nutrient Composition of Experimental Feeds}

Although OG contained more OM, the relatively higher ADF composition of OG than in FSF may presumably reduce its digestibility (McDonald et al., 2002). Moreover, the higher NDF value in OG could influence voluntary feed intake and its efficiency to support the proliferation of rumen microbes due to its lower readily fermentable nutrients than FSF. This implies that OG may negatively influence the digestibility of the fibrous basal diet and its utilization making it less worthy than FSF in improving animals' performance. In another word, FSF had higher neutral detergent soluble $(68.07 \%)$ than OG $(60.22 \%)$ that could support rumen microbes as sources of soluble carbon. Thus, FSF could be an important alternative energy supplement than OG to animals as depicted by its chemical concentration as well as less competition for FSF with human as food than OG.

\section{Carcass Yields and Primal Cuts}

The absence of statistically significant difference in carcass yield and cut values between the control and other treatments could be an attribute of supplementation of all animals with isonitrogenous diets. Supplementation of NSC could have made sufficient amount of protein source available to the rumen microbes to proliferate, thereby enhanced the utilization of nutrients in the hay by the animal (Krebs et al., 2007; Ben Salem et al., 2002). Burrin (2002) noted that some dietary essential amino acids and nearly all of the nonessential amino acids are converted to energy in the first compartments of the small intestine, when animals consume feeds deficient in energy. Such mechanisms must have helped the lambs to compensate the energy limitations in the control diet. Nevertheless, the lower carcass yield and cut values for sheep that consumed control diet indicates that supplementation of FSF, OG or their mixture had improved performance of the lambs.

The higher dressing percentage in 100FSF could be an attribute of the higher hot carcass weight $(8 \mathrm{~kg})$ compared to OFSF $(7.26 \mathrm{~kg})$ and the higher offal content in OFSF than 100FSF, since dressing percentage in this particular study was calculated with slaughter weight as a numerator than empty body weight. The higher mean carcass yield in sheep consumed 100FSF implies that supplementation of FSF have improved the meat production of Hararghe highland sheep as compared to OG diets. The result of carcass yield in the present study was $40.6 \%$ more than the carcass yield obtained from rams managed under farmers' conditions (Kefyalew et al., 2013), but similar with carcass obtained from the same breed of lambs supplemented with $350 \mathrm{~g}$ commercial concentrate mix to a basal diet of urea treated maize stover (Hirut et al., 2011). The Dressing percentage obtained in the present study fall within a range (36.7$45.2 \%$ ) reported for other indigenous sheep breeds supplemented with different diets (Takele and Getachew, 2011; Getnet et al., 2008; Jemal et al., 2005)

\section{Edible and Non-edible Offal Components}

The feeds the animals consume affect not only the growth of live body weight and carcass, but also mass of all viscera organs (Lawrence and Fowler, 2002). In the present study, the development of the majority of the organs remains similar. This similarity between the growths of most viscera organs could be due to the fact that these organs develop at early age of the animals (Yun et al., 2003) and less influenced by supplementation. Since the diets used in the study contain low levels of plant secondary metabolites, higher weight of the liver and kidney displayed in OFSF treatment group than the control may not be related to toxic effect of the diet (Getnet et al., 2008), rather it may be associated to less glycogen store or slower development of this organs in lambs fed the control diet. The higher growth of gut for lambs consumed maximum OG levels (OFSF) might have been due to higher fiber content of the diets (OG). High fiber diets having large amounts of undigested material entering the small intestine result in net tissue growth. Fluharty et al. (1999) also noted higher GIT organs weight growth in lambs' grazed alfalfa dominated high fiber pasture than those consumed mixed concentrate diets. The result for TEOC in the present study (range, 3.16$3.47 \%$ ) was higher than obtained by Tsehay (2012) in Hararghe highland sheep (2.7-3.2\%) fed a basal diet of natural pasture hay and supplemented with graded levels 
of onion leaves as a substitute for wheat bran in concentrate mixture. But, it falls within a range $(2.22 \mathrm{~kg}-$ $4.19 \mathrm{~kg}$ ) reported by Hirut et al. (2011) in the same sheep breed fed urea treated maize stover basal diets supplemented with different concentrate mixture. Similar to the present study, Malisetty et al. (2013) reported significantly different weight of edible organs in Nellore ram lambs consumed maize silage basal diets and supplemented with different levels of concentrate, while Madhavi et al. (2006) noted no considerable difference between edible viscera organs for this breed of ram lambs fed differently processed detoxified neem (Azadirachta indica) seed cake based complete diet.

Evaluation of non-edible organs may help in the diagnosis of abnormal physiology that indirectly influences the status of the edible viscera or carcass components. For example, pancreas is a viscera organ where most digestive enzymes and hormones are secreted (McDonald et al., 2002) and hence affects all the organs' system performance. In the present study, there was no abnormal increase or decreases in the size of any of the non-edible viscera organs. The total non-edible offal component ranged $8.42 \mathrm{~kg}-9.43 \mathrm{~kg}$ was slightly higher than the same breed of sheep $(8.09 \mathrm{~kg}-8.39 \mathrm{~kg})$ fed urea treated maize Stover supplemented with concentrate mix (Hirut et al., 2011). Generally, lambs fed with the treatment diets recorded higher weights of edible and non-edible organs, at least in magnitude, than control diet. Thus, supplementing FSF to Hararghe highland lambs fed with natural pasture basal diets could produce higher offal than the non-supplemented groups.

\section{Carcass Composition}

The variation in nutrient composition of feeds consumed by animals affects carcass composition (Plam, 2004) and thereby sensory quality of meat (Melton, 1990). Higher moisture content of carcass enhances microbial growth for spoilage, and reduces shelf life and taste of meat (Lawrie and Ledward, 2006). The moisture contents of the carcass in the present study were within the normal range for lambs (Santoso et al., 2008; Hui et al., 2001). Nevertheless, higher moisture content in treatments supplemented with concentrate containing high level of FSF may be an indication that use of this feed resource at high level than the present may impart some undesirable properties to the carcass.

The increase in ether extract with increased level of OG in the present study could be due to higher fiber content of OG than FSF. Feeds with high fiber results in more volatile fatty acids production in the rumen and enhance mutton fat, thereby the crude fat percentage of the carcass. Optimum fat content of meat improves juiciness, flavor, and texture, but if the level increases above optimum, it negatively affects the flavor due to production of volatiles (Melton, 1990). This may raise blood cholesterol level, a risk factor for cardiovascular disorder. The optimum lipid value for meat is $5 \%$ of the carcass (Hui et al., 2001), which was nearly similar with the EE content of lambs (5.3\%) fed 100FSF, unlike the $6.7 \%$ for those fed with OFSF $(100 \%$ OG) in the present study. The EE value of all lambs in the present study was less than the value $(14.8-25.7 \%)$ reported by Kiyanzad (2005) for lambs of different breeds. Moloney et al. (2002) and Chan et al. $(1995,1996)$ noted fat content of 7.5$9.4 \%$ in lamb meat to be normal for consumption in human diets. The fact that fatty acids and fats are components of ether extract (crude fat); the low value for EE percentage (4.87-6.77\%) observed in the present study is an indicator of meat quality from this breed of lambs.

The CP content of mutton in the present study is higher than the value reported in earlier studies (13.4$18 \%$; Kiyanzad, 2005). The consistent increase in crud protein (CP) content of the meat with increasing level of FSF inclusion indicates the leanness of the meat in groups fed with FSF containing diets than the sole oat grains. This could be due to higher protein to energy ratio in the lower digestive tract of the lambs. Moreover, the readily soluble energy nutrients of the FSF might have contributed to the proliferation of the rumen microbes, which produced quality microbial protein available for lower gut digestion and absorption, thereby improving lean muscle development in meat, which is the most preferable characteristic in mutton.

\section{Carcass pH Concentration}

The main factor determining the quality of meat is its $\mathrm{pH}$, because it is related to biochemical processes during the transformation of muscle to meat (Bas et al., 2000). Consequently, changes in the $\mathrm{pH}$ during the post-mortem period influence the organoleptic characteristics of the meat. All the readings of $\mathrm{pH}$ in the present study fall within the range of 7.42 to 5.84 when measured at initial time of 45 minutes and 24 hours post-evisceration, respectively indicating that the $\mathrm{pH}$ of meat consistently decreased with time due to progress in lactic acid production as expected naturally. Hence, it was shifted from slightly alkaline to acidic condition. After 24 hours of evisceration, only 100FSF (5.41) and 67FSF (5.71) resulted in values, which are considered optimum meat $\mathrm{pH}$ (Ameha, 2008).

The $\mathrm{pH}$ of mutton from lambs consumed control diets is high compared to all other treatment diets. This could presumably be due to relatively lowest glycogen reserve in their longisimus dorsi muscle that can result in lactic acid production for the reduction of the $\mathrm{pH}$. At $\mathrm{pH}$ of 5.4 5.5 the post mortem glycolysis may still contain as much as $1800 \mathrm{mg}$ residual glycogen/100 $\mathrm{g}$ muscle. This can increase the water-holding capacity and tenderness of the muscles when cooked (Immonen et al., 2000). On the other hand, Lawrie and Ledward (2006) noted that residual glycogen does not exist if the $\mathrm{pH}$ fails to less than 5.4 during post-mortem glycolysis. Similarly McIntyre (2000) suggested that muscle $\mathrm{pH}$ value above 5.7 is unacceptable and results in rigor and stiffness of longisimus dorsi muscle. According to Ameha (2008) good quality meat usually has a $\mathrm{pH}$ of $5.4-5.7$ when determined at 45 minutes post slaughter.Young (2001) suggested that meat $\mathrm{pH}$ above 5.9 has bad storage value for two reasons: First putrefactive bacteria such as Shewanella putrefaciens and Yersinia enterocolitica are able to grow anaerobically on meat and second, the glucose concentration is lower as $\mathrm{pH}$ increases. When glucose becomes absent due to microbiological activity, the microflora begin to use amino acids as an energy source, generating offensive catabolic products. Therefore, the $\mathrm{pH}$ that occurred in sample from lambs fed with 100FSF at 18 hours and 67FSF at 24 hours indicate that desired meat characteristics with longer shelf life can be obtained by feeding lambs with 100FSF diet. 


\section{CONCLUSION}

This study demonstrated that inclusion of FSF in the diet of Hararghe highland lambs as a replacement for oat grains improved carcass yield and quality, particularly at higher level of inclusion. Hence, it can be concluded that FSF can be used as energy supplement for sheep and can replace oat grain or other concentrate with similar composition for use in small holder sheep production systems.

\section{Acknowledgements}

We would like to thank Harmaya University for allowing using research facilities and laboratory and the Swedish International Development Agency (SIDA) for providing the research fund.

\section{Conflict of Interest}

Conflict of Interest None declared

\section{REFERENCES}

AACC. (2000). American Association of Cereal Chemists: Approved Methods. St. Paul, MN, AACC No. 86-06, 4070.

Abebe, H., Solomon, M., Berhan, T. andAsaminew, T. (2011). Body weight and carcass characteristics of Washera sheep fed urea treated rice straw supplemented with graded levels of concentrate mix. Livestock Research for Rural Development 23 (12): 2011.

Adane, H. (2008). Sheep and Goat Economics of Production and Marketing. In: Alemu Yami and R.C. Merkel (eds.) Sheep and Goat Production Hand book for Ethiopia: Ethiopia Sheep and Goat Productivity Improvement Program (ESGPIP); Pp: 297-324.

Adane, H. and Girma, A. (2008). Economic significance of sheep and goats. In: AlemuYami and R.C. Merkel (eds.) Sheep and Goat Production Hand book for Ethiopia: Ethiopia Sheep and Goat Productivity Improvement Program (ESGPIP); Pp. 2-4

Addass, A., Perez, L.K.A., Midau, L.A., Lawan A.U. and Tizhe, M.A. (2010). Haemato-Biochemical Findings of Indigenous Sheep Breeds in Mubi Adamawa State, Nigeria. Global Veterinaria 4(2): 164-167.

Adugna, T. (2007). Feed resources for producing export quality meat and livestock in Ethiopia. Examples from selected woredas from Oromia and SNNP regional states. Hawassa University, Ethiopia.

Alemu, Y. (2008). Nutrition and feeding of sheep and goats. In: Alemu Yami and R.C. Merkel (eds.) Sheep and Goat Production Hand book for Ethiopia: Ethiopia Sheep and Goat Productivity Improvement Program (ESGPIP). PP: 103-159.

Amha, S. (2008). Sheep and Goat Meat Characteristics and Quality. In: Alemu Yami and R.C. Merkel (eds.) Sheep and Goat Production Hand book for Ethiopia: Ethiopia Sheep and Goat Productivity Improvement Program (ESGPIP). PP: 325-340.

AOAC. (1995). Official Methods of Analysis of AOAC International, $16^{\text {th }}$ edition. Standard compendium of laboratory methods for analyzing foods and related substances. AOAC, Gaithersburg, MD.

Bas, P., Beriain, M.J., Purroy, A., Treacher, T. (2000). Effect of animal and nutritional factors and nutrition on lamb meat quality. In: Ledin I. (ed.), Moran d-Fehr P. (ed.). Sheep and goat nutrition: Intake, digestion, quality of products and rangelands. Zaragoza: CIHEAM, 2000. p. 75-86 (Cahiers Options Méditerranéennes; n. 52).

Ben Salem, H.A., Nefzaoui and Ben Salem, L. (2002). Supplementation of Acasia Cyanophylla lind foragebased diets with barley or shrubs from arid areas (opuntiaficusindica $f$. inermis and AtriplexnummulariaL.) on growth and digestibility in lambs. Animal feed Science and Technology 96(1): 15-30.

Burrin, D.G. (2002). Gastrointestinal protein and amino acid metabolism in growing animals. In: Pierzynowski, S.G., Zabielski, R. (Eds.), Biology of Growing Animals. In: Zabielski, R., Gregory, P.C., Weström, B. (Eds.). Biology of the Intestine in Growing Animals 1: 695-725.

Chan W., Brown J., Lee S.J. and Buss D.H. (1995). Meat, Poultry and Game. Fifth Supplement to McCance and Widdowson's The Composition of Foods, $5^{\text {th }}$ ed. London: HMSO.

Chan W., Brown J., Church S.M. and Buss D.H. (1996). Meat Products and Dishes. Sixth Supplement to McCance and Widdowson's The Composition of Foods, 5th ed. London: HMSO.

Connolly, L . (2000). Economic performance in Irish sheep production. Teagasc Research Centre, Athenry, Co. Galway, Denmark.

Edward, A.E. (2011). Marginal Analysis: An Economic Procedure for Selecting Alternative Technologies/ Practices1. Florida Cooperative Extension Service, Institute of Food and Agricultural Sciences, University of Florida, Gainesville, USA.

Fluharty, F.L., McClure, K.E., Solomon, M.B., Clevenger, D.D. and Lowe, G.D. (1999). Energy source and ionophore supplementation effects on lamb growth, carcass characteristics, visceral organ mass, diet digestibility, and nitrogen metabolism. Journal of Animal Science 77: 816-823.

Getnet, A., Kijora, C., Kehaliew, A., Bediye, S. and Peters, K. J. (2008). Evaluation of Tagasaste (Chamaecytisus palmensis) forage as a substitute for concentrate in diets of sheep. Livestock Science 114: 296-304.

Hirut, Y., Solomon, M. and Mengistu, U. (2011). Effect of concentrate supplementation on live weight change and carcass characteristics of Hararghe Highland sheep fed a basal diet of urea-treated maize stover. Livestock Research for Rural Development 23(12).

Hui, Y.H., Wai-Kit, N., Rogers R.W., Young, O.A. (2001). Meat Science and applications; PP: 16-24; Marcel Dekker, Inc. New York.

IGAD (Intergovernmental Authority on Development) Livestock Policy Initiative. (2009). The Contribution of Livestock to the Economies of IGAD Member States. Study Findings, Application of the Methodology in Ethiopia and Recommendations for Further Work. IGAD LPI Working Paper No. 02-10.

Immonen, K., Ruusumen, E. and Puolanne, E. (2000). Some effects of residual glycogen concentration on the physical and sensory quality of normal pH beef. Meat Science 55 (1): 33-38.

Jemal, D., Chala, M., Diriba, G., Ulfina, G., Diriba, D., Adane, $\mathrm{H}$. and Temesgen, J. (2005). Weight gain, carcass Characteristics and Economic Evaluation of Horro sheep supplemented with different substitution level of maize grain and molasses. In: Ethiopia society of Animal production ( ESAP ) proceeding 13th annual conference held at Addis Ababa, Ethiopia. 
Diriba Diba et al.,

Kefyalew, B., Banerjee, S. and Yigrem, S. (2013). Carcass Traits of Arsi-bale Sheep and Goat Reared under Farmers Management System in Sidama Region of Southern Ethiopia. Middle-East Journal of Scientific Research 13(11): 1465-1470.

Khan, B.B., Arshad, I. and Mustafa, M.I. (2003). Sheep and goat production, Department of Livestock Management University of Agriculture Faisalabad, Pakistan; PP: 4-10.

Krebs, G.L., Howard, D.M. and Dods, K. (2007). Feeding AcasiaSaligna with sheep and goats with or without the addition of urea or polyethylene glycol. Asian-Australian Journal of Animal Science 20(10): 1551-1556.

Kiyanzad, M.R. (2005). Comparison of Carcass Composition of Iranian Fat-tailed Sheep. Asian-Australian Journal of Animal Science 18(9): 1348-1352.

Lawrence T.L.J. and Fowler V.R. (2002). Growth of Farm Animals. Second Edition, PP: 1-6, Wallingford, UK.

Lawrie, R.A. and Ledward, D.A. (2006). Lawrie's Meat science. Seventh Editions. PP: 86-175. Cambrdige, England.

Madhavi, K., Reddy, T. J., Reddy R. Y. and Reddy, G.V.N. (2006). Effect of feeding differently processed detoxified neem (Azadirachtaindica) seed cake based complete diet on growth, nutrient utilization and carcass characteristics in Nellore sheep. Livestock Research for Rural Development 18(10): 2006.

Malisetty, V., Yerradoddi, R.R. and Jatoth, N. (2013). Effect of feeding maize silage supplemented with concentrate / legume hay on carcass characteristics in Nellore ram lambs. International Journal of Science, Environment and Technology 2(2): 128-132.

McDonald, P., Edwards, R.A., Greenhalgh, J.F.D. and Morgan, C.A. (2002). Animal Nutrition. $6^{\text {th }}$ eds. Prentice Hall, London. PP: 4-9

Mclntyre, B. (2000). Reducing dark-cutting in beef carcases. Farmnote 61/00, Department of Agriculture and Food, Western Australia; (http://www.agric.wa.gov.au/objtwr/ imported assets//content/aap/bc/m/f06100.pdf).

Melton, S.L. (1990). Effects of Feeds on Flavor of Red Meat: A Review. Journal of Animal Science 68: 4421-4435.

Moloney, A. P.,Teagasc and Dunsany. (2002). The fat content of meat and meatproducts, Woodhead Publishing Ltd, pp: 1-17.

Moran, J. (2005). How energy is measured. In: TROPICAL DAIRY FARMING. Feeding Management for Small Holder
Sci. Technol. Arts Res. J., Oct-Dec 2015, 4(4): 09-17

Dairy Farmers in the Humid Tropics. National Library of Australia Cataloguing-in-Publication entry. PP. 30-32.

Pla M. (2004). Effects of nutrition and selection on meat quality; Proceedings -8th World Rabbit Congress September 7-10, 2004, Puebla, Mexico.

Santos, V.A.C., Silva, S.R. and Azevedo, J.M.T. (2008). Carcass composition and meat quality of equally mature kids and lambs, Journal of Animal Science 86: 19431950.

SAS (Statistical Analysis System). (2008). The Little SAS® Book: A Primer, Fourth Edition, version 9.1.3. Statistical analysis system institute Inc., NC. USA.

Takele, F. and Getachew, A. (2011). Effect of supplementing wheat bran, Acacia albida leaf meal and their mixture on feed intake and carcass characteristics of Horro sheep fed vetch (Lathyrussativus) haulm basal diet. Livestock Research for Rural Development 23(4): 2011.

Tsehay, R. (2012). Effect of graded levels of onion leaves as a substitute for wheat bran in concentrate mixture on performance and carcass characteristics of Hararghe highland sheep; A Thesis Submitted to the School of Graduate Studies (School of Animal and Range Sciences); Haramaya University; In Partial Fulfilment of the Requirement for the Degree of Master of Science In Agriculture (Animal Nutrition); P.O. Box: 138 Dire Dawa, Ethiopia

Upton, M. (1979). Farm Management in Africa: The Principle of Production and Planning. Oxford University Press, Great Britain. pp. 282-298.

Van Soest, P.J. and Robertson, J.B. (1985). Analysis of forage and fibrous feeds. A laboratory manual for Animal Science, Cornell University, Ithaca, New York, USA.

Yoseph, M., Azage, T., Alemu, Y. and Umunna, N. N. (2002). Evaluation of non-conventional agro-industrial byproducts as supplementary feeds for ruminants: in vitro and metabolism study with sheep. Small Ruminant Research 44: 25-35.

Young O.A. (2001). Carcass Processing: Factors Affecting Quality. In: Hui Y H., Nip Wai-Kit, Rogers R. W., Young O. A. (edns). Meat Science and Applications, Marcel Dekker, Inc., New York, NY.

Yun, S.G., Cho, W.M., Lee, S.C. and Kim, C.H. (2003). Effects of Feeding Method of Compound Feed on the Development of the Digestive Organs and Other Internal Organs of Hanwoo Steers. Asian-Australian Journal of Animal Science 16: 1315-1319. 